\title{
ISLAMISASI SEBAGAI RESPON PENSEKULARAN ILMU-ILMU MODERN
}

\author{
Muhammad Zulfunun \\ Program Studi Komunikasi Penyiaran Islam, Fakultas Agama Islam, Universitas Ibn Khaldun \\ Bogor, Indonesia \\ Email: Ibnuhasly@gmail.com
}

\begin{abstract}
Aware of the danger generated by modern western science negating the role of God who then learned by the Muslims, in turn spawned an active response and positive of the Muslims Scientists in view sekularization science is there to do Islamization of modern western science. This type of research is the approach literature study (library research). Ie research that the data source is obtained through books, journals and other related publications media. This paper describes the what, why and how the form of Islamisation developed by Muslim scientists as a response to sekularization contemporary sciences there.
\end{abstract}

Keywords: Islamization, Science, Knowledge

\begin{abstract}
Abstrak
Sadar akan bahaya yang ditimbulkan oleh ilmu-ilmu Barat Modern yang menegasikan peran Tuhan yang kemudian dipelajari oleh kaum muslimin, pada akhirnya melahirkan respon aktif dan positif dari kalangan ilmuan muslim dalam melihat pentidakislaman ilmu-ilmu yang ada untuk melakukan islamisasi ilmu-ilmu Barat modern. Jenis penelitian ini adalah menggunakan pendekatan studi pustaka (library research). Yaitu penelitian yang sumber datanya diperoleh melalui buku-buku, jurnal dan media publikasi lainnya yang berkaitan. Tulisan ini memaparkan tentang apa, kenapa dan bagaimana bentuk dari islamisasi yang dikembangkan oleh para ilmuan muslim tersebut sebagai sebuah respon terhadap pensekuleran ilmu-ilmu kontemporer yang ada.
\end{abstract}

Kata Kunci: Islamisasi, Sains, Ilmu

\section{Pendahuluan}

Wacana Islamisasi sains sebenarnya berwujudsejak lama, bahkan semenjak Muhammad $S A W$ diutus sebagai Nabi dan Rasul lebih 1.400 tahun yang lalu. Dalam masa turunnya wahyu selama 23 tahun, baginda Rasulullah $S A W$ telah mengubah paradigma jahiliyah pelbagai sudut kehidupan manusia ke prinsip dan tauhid kepada Allah SWT (Saefuddin, 2010).

Proses Islamisasi sains lebih jelas tampak pada era pemerintahan Abbasiyah ketika kegemilangan Islam memuncak. Sarjana-sarjana Islam pada zaman tersebut diberi amanah dan kepercayaan untuk menerjemahkan dan sekaligus mengislamisasi karya-karya Yunani, Persi dan India kedalam bahasa Arab.

Konsep dan kerangka pengislaman ilmu tersebut tentu berdasarkan al-Qur'an yang menegaskan bahwa ilmu itu tidak terpisahkan dari Allah Yang Maha Esa. Ayat-ayat terawal diturunkan kepada Nabi Muhammad $S A W$, dalam surat al-Alaq

(C)2020 The authors and Komunika. All rights reserved. 
(95) ayat 1-5, menggariskan dengan jelas semangat Islamisasi sains kontemporer ketika Allah SWT menekankan bahwa Dia adalah sumber dan asal ilmu manusia(Saefuddin, 2010).

Pada zaman pertengahan, Islamisasi telah dilakukan khususnya oleh para teolog muslim seperti al-Ghazaly, Fakhruddin ar-Razi, Syafuddin al-Amidi dan lain-lain dengan penegetahuan Islam yang mendalam mereka menyaring filsafat Yunani kuno untuk disesuaikan dengan pemikiran Islam. Sebagai hasilnya, ada hal-hal dari filsafat Yunani kuno yang diterima dan ada yang ditolak (Saefuddin, 2010).

Maka secara sederhana Islamisasi sains dapat dikatakan sebagai sebuah upaya untuk mengaitkan kembali hukum alam (sunnatullah) dengan al-Qur'an yang keduanya pada hakikatnya merupakan ayat-ayat keagungan Tuhan.

Meskipun proses Islamisasi telah wujud sejak awal Islam, namun istilah Islamisasi sains sendiri mengemuka setidaknya tahun 1970-an hingga 1990-an, tetapi istilah ini meredup dan muncul lagi akhir-akhir ini. Islamisasi sains modern muncul sebagai respon terhadap hegemoni dunia Barat atas dunia Muslim, bukan saja dalam kancah politik, ekonomi dan budaya, namun termasuk juga ilmu pengetahuan. Istilah dewesternisasi ilmu atau islamisasi ilmu kontemporer pertama kali dicetuskan oleh Syed Muhammad Naquib al-Attas pada Persidangan Dunia Pertama tentang Pendidikan Islam di kota makkah pada tahun 1977 (Saefuddin, 2010).

Sains modern dengan semua kemegahan dan kesuksesannya, tak luput dari dimensi gelapnya. Yang kalau dibiarkan atau tidak disadari, bisa menimbulkan dampak negatif, terutama pada sisi teologis. Betapa tidak, pembatasan dirinya hanya pada dunia empiris, sebagai konsekwensi dari basis positivisnya, telah membuat sains mengabaikan dunia non-empiris, yang kita sebut alam gaib, bahkan cenderung mengabaikan keberadaannya. Padahal kepercayaan pada dunia gaib merupakan ajaran agama yang fundamental, khususnya kalau disadari bahwa Tuhan sendiri, yang dipandang sebagai sumber dari segala yang ada dan bahkan pencipta alam semesta bersifat ghaib atau non-fisik (Kartanegara, 2006). Sains mengesampingkan wujud Allah sebagai Tuhan Maha Pencipta, Maha Penentu, Maha Tahu, Maha Mengatur, semua ini tidak disebutkan di dalam sains. Bahkan terang-terangan tokoh sains mengumumkan bahwa Tuhan telah mati, seperti dikatakan oleh Nietzsche. Oleh karena itu tidak heran kalau umat Islam, terutama kaum intelektualnya memberi reaksi yang beragam terhadap teori-teori ilmiah Barat yang sekuler begitu mereka mengenal baik teori-teori tersebut, termasuk upaya pemikir besar Muslim kontemporer, seperti: Naquib al-Attas, Ismail R. Faruqi, Nasr untuk mengislamkan sains modern (Thalib, 1999).

\section{Makna Islamisasi Sains}

Islamisasi adalah kata benda dari mengislamkan, yaitu suatu upaya untuk menjadikan Islam atau bersifat Islami. Sesuatu yang perlu diislamkan berarti sebelumnya tidak atau belum Islam (Thalib, 1999). Ide Islamisasi ilmu pengetahuan muncul dari premis bahwa ilmu pengetahuan kontemporer tidak bebas nilai (value-free), tapi sarat nilai (value-laden) yang berupa paradigma, ideology atau pemahaman seseorang (Thalib, 1999). 
Meskipun masih banyak dikalangan ilmuan, baik Barat maupun ilmuan muslim sendiri yang meragukan bahkan menafikan adanya sains Islam. Sains itu netral, kata mereka, sehingga tidak ada sains Islam, sains Kristen, sains Hindu, dan sebagainya. Sains adalah sains, netral dan universal, seperti yang diyakini oleh Abdussalam, seorang saintis Muslim penerima hadiah nobel di bidang fisika tahun 1980-an (Handrianto, 2016).

\section{Definisi Sains}

Sains (science) secara etimologis berasal dari bahasa Latin scio (saya tahu/I know), scientia (pengetahuan/knowledge) atau scire (menegtahui/to know) yang juga bererti pengetahuan atau mengetahui. Jadi pada dasarnya secara bahasa sains merupakan padanan kata terhadap 'ilm dalam bahasa arab,. Scire sendiri adalah padanan dari episteme dalam bahasa Yunani, yang menurut Plato adalah: Knowledge is true belief with an account (logos), pengetahuan adalah keyakinan yang benar dengan suatu penalaran (Ishaq, 2014).

Dalam pembagiannya sains dapat dibagi menjadi beberapa bagaian, anatara lain: Sains Kealaman, Sains Sosial, Humaniora (Tafsir, 2013).

Penggunaan istilah sains (episteme) sendiri dalam bahasa Yunani pada awalnya berarti filsafat spekulatif dan teoritis yang meliputi fisika, matematika, etika yang dibedakan dengan tekne yang bersifat keterampilan seperti music, olehraga dan sebagainya. Kemudian dalam perkembangannya makna sains menyempit bersamaan dengan berkembangnya faham rasionalisme dan empirisme di Eropa (Ishaq, 2014).

Sains kemudian tereduksi menjadi pengetahuan yang dihasilkandan diuji dari suatu metode saintifik yang mengandakan pengamatan empiric dan rasio, atau pengetahuan yang memenuhi kriteria: logico-hypotetico-verificatif, bermakna sesuatu itu harus logis, terdapat suatu hipotesis yang menjelaskannya, dan harus dibuktikan dengan data empiris (Ishaq, 2014).

Dampaknya adalah sains mengabaikan dunia non-empiris, yang kita sebut alam ghaib. Bahkan cenderung mengabaikan kebenarannya. Padahal kepercayaan pada dunia ghaib merupakan ajaran yang mendasar bagi ummat Islam, khususnya juka disadari bahwa Allah SWT sendiri, yang dipandang sebagai sumber dari segala yang ada bahkan sebagai pencipta alam semesta bersifat ghaib atau non-fisik.

Penolakan beberapa ilmuan besar dunia, seperti Laplace, Darwin, Freud, Emile Durkheim, terhadap eksistensi Tuhan, merupakan konsekwensi logis dari pembatasan lingkup sains modern pada dunia empiris dan metode ilmiah yang diciptakannya. Bahkan filosof besar Barat seperti Bertlrand Russel filosof logika positivism, mengatakan bahwa pembicaraan berkaitan dengan dunia non-empiris harus dipandang sebagai non-sensikal, artinya tidak berguna sama sekali (Kartanegara, 2006).

Dalam sejarah kebudayaan Barat, justeru sebab pengalaman buruknya dengan agama, maka ilmu sains berkembang maju. Namun meskipun banyak maslahat yang dihasilkan oleh sains tersebut banyak juga keburukan yang ditimbulkan oleh peradaban Barat. Mereka dapat menuasai bumi, tetapi tidak dapat menguasai diri, mengenali diri, membawa pada ketentuan dan ketentraman pada diri (al-Attas, 2001). 
Sains Barat sekuler inilah yang cenderung merusak alam, mencemari udara dan air dengan limbah industri, merusak keseimbangan unsur hara dalam tanah, menghancurkan keseimbangan ekosistem lingkungan, melubangi hingga perut bumi untuk mengeruk mineral, barang tambang dan apa saja yang dijual dengan semena-mena tanpa mempertimbangkan aspek ekologis, meracik bahan-bahan kimia beracun untuk makanan dan obat-obatan demi keuntungan sesaat, semua itu semata demi keuntungan pemodal yang menggunakan keahlian saintis. Tidaklah mengherankan karena memang itulah materi yang mereka kejar semenjak mereka mempelajari sains (Ishaq, 2014).

al-Attas dalam bukunya, Islam dan Sekularisme, mengkritisi. Bahwa tidak ada tantangan yang serius dan merusak saat ini daripada peradaban Barat. Barat menjadikan hakikat ilmu menjadi bermasalah karena kehilangan tujuan. Ilmu yang mestinya menciptakan keadilan justru membawa kekacauan dalam kehidupan manusia. Menghasilkan kekeliruan dan skeptisisme, yang mengankat keraguan ke derajad ilmiah. Ilmu yang pertamakalinya dalam sejarah telah membawa kekacauan pada tiga kerajaan alam yakni : hewan, tanaman dan bahan galian (mineral) diri (al-Attas, 2001).

\section{Proses Islamisasi Sains}

Kesadaran bahwa sains Barat modern adalah ateis secara alami dan oleh karena itu perlu diislamkan, pertama kali terdengar di awal tahun 1930-an, melalui Muhammad Iqbal namun tidak menjelaskan atau mendefinisikan gagasannya. Syed Hosen Nasr pada tahu 1960 secara implisit merujuk metode Islamisasi sains modern dengan menyarankan bahwa yang terakhir harus ditafsirkan dan diterapkan dalam konsepsi Islam tentang kosmos, Ismali R. al-Faruqi yang diuntungkan dengan tulisan al-Attas kemudian mempopulerkan agenda Islamisasi ke banyak bagian dunia muslim (Daud, 2013).

Awal munculnya Islamisasi ilmu di dunia Islam tidak dapat dilepas dari sejarah. Pelebaran sayap dakwah Islam bukan tanpa konsekwensi. Terjadi penyerapan terhadap budaya setempat. Dimana, unsur-unsur, nilai-nilai masyarakat ditampung, tampih da disaring dulu sebelum diserap. Syed Hossein Nasr menjelaskan bahwa, ada masa pemindahan, namun ada juga masa pengunyahan, penceraan, dan penyerapan yang juga berarti penolakan. Tidak pernah ada sains yang diserap ke dalam sebuah peradaban tanpa penolakan sedikit pun (Handrianto, 2010).

Nasr menganggap sekularisme sebagai segala sesuatu yang asalnya hanyalah dari manusia, bukan dari Tuhan dan yang landasan metafisikanya adalah pemisahan ontologis antara manusia dan Tuhan. Ia juga menulis tentang program sentral mengenai perlunya mengislamkan ilmu pengetahuan yang dihadapi umat Islam di dunia modern ini (Daud, 2003).

Pernyataan lain muncul dari Ismail Raji al-Faruqi, terkait dengan Islamisasi Pengetahuan, dalam bukunya Islamization of knowledge: general principles and workplan yang diterjemahkan dalam bahasa Indonesia, Islamisasi Pengetahuan. Faruqi menjelaskan bahwa tugas terberat yang dihadapi umat Islam abad ini adalah memecahkan masalah pendidikan. Pasalnya dalam pendidikan kaum muslimin 
terjadi dualisme pendidikan yakni sistem pendidikan Islam dan sistem pendidikan sekueler (al-faruqi, 1984). Lebih lanjut ia menjelaska bahwa:

Pada masa sekarang ini, manusia-manusia non-Muslim adalah ahli-ahli yang tak dapat diragukan di dalam semua disiplin tersebut. pada masa sekarang ini, universitas-universitas Dunia Islam, buku-buku, prestasi-prestasi, world view, masalah-masalah dan ideal-ideal non-Muslim diajarkan kepada pemuda-pemuda Muslim. Pada masa sekarang ini pemuda muslim di-westernisasikan oleh guru-guru Muslim di universitas-universitas Muslim. (al-faruqi, 1984).

Tidak hanya itu Faruqi pun merumuskan rencana kerja untuk menjalankan proses Islamisasi pengetahuan ini, yakni: Penguasaan disiplin ilmu modern, penguasaan khazanah warisan Islam, membangun relevansi Islam dengan masingmasing disiplin ilmu modern, memadukan nilai-nilai dan khazanah warisan Islam secara kreatif dengan ilmu-ilmu modern, dan mengarahkan aliran pemikiran Islam ke jalan-jalan yang mencapai pemenuhan pola rencana Allah SWT (al-faruqi, 1984).

Sementara itu untuk mewujudkan tujuan-tujuan tersebut, Faruqi menyusun 12 langkah yang harus ditempuh terlebih dahulu. Langkah-langkah tersebut adalah: Penguasaan disiplin ilmu modern, survey disiplin ilmu, peguasaan khazanah Islam: ontology, penguasaan khazanah ilmiah Islam: analisis, penentuan relevansi Islam yang khas terhadap disiplin-disiplin ilmu, penilaian secara kritis terhadap disiplin keilmuan modern dan tingkat perkembangannya di masa kini, penilaian secara kritis terhadap khazanah Islam dan tingkat perkembangannya dewasa ini, survei permasalahan yang dihadapi umat islam, survei permasalahan yang dihadapi manusia, analisis dan sintesis kreatif, penuangan kembali disiplin ilmu modern ke dalam kerangka Islam, dan penyebarluasan ilmu yang sudah diislamkan (al-faruqi, 1984).

Adapun bagi Syed Naquib al-Attas, merumuskan Islamisasi sebagai pembebasan manusia dari tradisi-tradisi yang berunsurkan kuasa sakti (magic), mitologi, animism, kebangsaan-kebudayaan yang bertentangan dengan Islam, dan sesudah itu pembebasan dari kungkungan sekuler terhadap akal dan bahasanya. Ia terbebaskan baik dari pandangan alam (worldview) yangberunsurkan kuasa sakti maupun pandangan alam yang sekuler (al-Attas, 2011).

Proses tersebut mengharuskan seseorang mengetahui secara mendalam mengenai pandangan hidup Islam dan Barat, maka proses Islamisasi baru dapat dilakukan. Sebabnya Islamisasi ilmu pengetahuan saat ini melibatkan dua proses yang saling terkait:

1. Mengisolasi unsur-unsur dan konsep-konsep kunci yang membentuk budaya dan peradaban barat, dari setiap bidang ilmu pengetahuan modern saat ini. Khususnya dalam ilmu pengetahuan humaniora. Bagaimanapun, ilmu-ilmu alam, fisika dan aplikasi harus diislamkan juga khususnya dalam penafsiranpenafsiran akan fakta-fakta dalam formulasi teori-teori.

2. Memasukkan unsur-unsur Islam beserta konsep-konsep kunci dalam setiap bidang dari ilmu pengetahuan saat ini yang relevan (Armas, 2015).

Jika kedua proses tersebut selesai dilakukan, maka Islamisasi akan membebaskan manusia dari magik, mitologi, animisme, tradisi budaya nasional yang bertentangan dengan Islam, dan kemudian dari control sekular kepada akal 
dan bahasanya. Islamisasi akan membebaskan akal manusia dari keraguan (shakk), dugaan (zann) dan argumentasi kosong (mira') menuju keyakinan dan kebenarn mengenai realitas spiritual, intelligible dan materi. Islamisasi akan mengeluarkan penafsiran-penafsiran ilmu pengetahuan kontemporer dari idiologi, makna dan ungkapan sekular (Armas, 2015).

\section{Model Islamisasi Sains}

Setidaknya dalam melihat ide Islamisasi ini ada lima pendekatan Islamisasi barat modern. Kelima konsep tersebut senantiasa berkembang dan mempunyai pengukut yaitu pendekatan Instrumental, justifikasi, sakralisasi, integrasi dan paradigma/worldview (Handrianto, 2016).

Pertama, instrumentalistik. Pendekatan ini merupakan suatu konsep yang menganggap ilmu atau sains sebagai alat (instrumen). Bagi merekayang berpandangan bahwa sains, terutama teknologi adalah sekedar alat untuk mencapai tujuan, tidak memperdulikan sifat dari sains itu sendiri. Yang penting sains tersebut bisa membuahkan tujuan bagi pemakainya.

Dalam pendekatan instrumentalistik konsep ilmu tidak bebas nilai tidak berjalan. Malah menganggap bahwa ilmu adalah bebas nilai. Meskipun menuai kritik konsep ini telah memberikan kesadaran bagi umat Islam untuk bangkit melawan ketertinggalan. Konsep ini hanyalah langkah awal untuk menuju pada konsep-konsep atau pendekatan lain selanjutnya.

Kedua, justifikasi. Maksud dari model ini ialah penemuan-penemuan ilmiah modern, terutama dibidang ilmu-ilmu alam diberikan justifikasi (pembenaran) melalui ayat al-Qur'an maupun hadits. Meskipun kritikan terhadap model ini cukup keras dengan menyatakan bahwa Islamisasi bukan ayatisasi. Diantara tokohnya ialah Maurice Bucaille.

Ketiga, sakralisasi. Artinya, sains modern yang sekarang ini bersifat sekular dan jauh dari nilai-nilai spiritualitas, diarahkan menuju sains mempunyai nilai sakral. Ide ini dikembangkang oleh seyyed Hossein Nasr. Kritik pada ide ini ialah karena menurut pandangan Nasr, sains sakral dibangun atas konsep semua agama sama pada level esoteric (batin). Sains sakral menafikan keunikan hanya milik Islam karena keunikan adalah milik semua agama.

Keempat, integrasi. Yaitu mengintegrasikan (menggabungkan) sains Barat dengan ilmu-ilmu Islam. Ide ini diketengahkan oleh Ismail R. al-Faruqi. Al-Faruqi menyimpulkan solusiterhadap dualisme pendidikan yang terjadi pada kaum muslimin saat ini adalah Islamisasi pengetahuan/sains. Sistem pendidikan harus dibenahi dan dualisme sistem pendidikan harus dihapuskan dan disatukan dengan jiwa Islam dan berfungsi sebagai bagian yang integral dari paradigmanya. Sistem pendidikan harus diisi dengan sebuah misi, yang tidak lain adalah menanamkan visi Islam, menancapkan hasrat untuk merealisasikan visi Islam dalam ruang dan waktu.

Konsep al-faruqi inilah yang sekarang ini banyak dikembangkan oleh para ilmuan. Mengingat organisasi yang dibentuknya (IIIT) bergerak sangat aktif. Tulisan-tulisan dan website mengenai Islamisasi sains yang banyak ditemukan di dunia maya sebagaian besar memakai konsep al-Faruqi ini. Namun, sayangnya 
pengembangan Islamisasi yang berkaitan dengan ilmu-ilmu alam (natural sciences) masih kurang.

Kelima, paradigma/worldview. Konsep yang dirasakan paling menyentuh akar permasalahan sains adalah konsep dengan pendekatan paradigma Islam. Ide Islamisasi sains seperti ini yang disampaikan pertama kali secara sistematis oleh al-Attas. Proses Islamisasi sains itu sendiri diakukan menurut al-Attas dengan dua cara yang saling berhubungan sesuai urutan. Pertama, ialah melakukan proses pemisahan elemen-elemen dan konsep-konsep kunci yang membentuk kebudayaan dan peradaban Barat. Kedua, memasukkan elemen-elemen Islam dan konsep-konsep kunci kedalam setiap cabang ilmu pengetahuan masa kini yang relevan. Jelasnya, ilmu hendaknya diserapkan dengan unsur-unsur konsep utama Islam setelah unsur-unsur dan konsep pokok dikeluarkan dari setiap ranting.

Menurut pandangan paradigma ini Islamisasi tidak bisa tercapai hanya dengan menempeli (melabelisasi) sains dan prinsip Islam atas sains sekular. Usaha yang demikian hanya akan memperpuruk keadaan dan tidak ada manfaatnya selama virusnya masih berada dalam tubuh sains itu sendiri sehingga sains yang dihasilkan pun mengambang, Islam bukan, Sekular pun juga bukan. Padahal tujuan dari Islamisasi itu sendiri adalah untuk melindungi umat Islam dari sains yang sudah tercemar. Islamisasi sains dimaksudkan untuk mengembangkan kepribadian muslim yang sebenarnya sehingga menambah keimanannya kepada Allah, dan dengan Islamisasi tersebut akan lahirlah keamanan, kebaikan, keadilan dan kekuatan iman.

Dengan demikian konsep Islamisasi sains secara paradigma ini akan berakar kuat dan sesuai dengan jiwaIslam. Dan akan melahirkan umat yang kuat karena di masyarakat terdapat banyak ulama-ulama yang saintis dan saintis-saintis yang ulama.

Dari semua model Islamisasi diatas, semua beranggapan bahwa ada yang salah dalam sains Barat yang sekular. Ziauddin sadrar menegaskan tentang pentingnya sains Islam. Sebuah sains yang operasional sangat dibutuhkan untuk membangun sebuah peradaban. Sebagai suatu sistem objektif untuk memecahkan masalah yang terkerangka sesuai dengan paradigmanya sendiri, sains Islam harus muncul dari lingkaran nilai-nilai dan konsep-konsep Islam yang abadi. Tanpa sains Islam, masyarakat muslim hanya akan menjadi bagaian dari Barat (Sardar, 2000).

\section{Kesimpulan}

Dari pembahasan yang telah peneliti lakukan, ada beberpa hal yang dapat disimpulkan:

Pertama Islamisasi sains ialah bagaimana seorang muslim memasukkan cara pandang Islam dalam berinteraksi dengan sains, sains yang merupakan bagian dari ilmu tidak boleh dilepas dari cara pandang Islam. Allahlah yang menciptakan alam dengan segala isinya, karena itu pendekatan terhadap sains mestilah juga memasukkan Tuhan dalam melihat sains itu sendiri. Meskipun pada perjalanannya para pencetus ide Islamisasi sains memiliki pengertian yang berbeda terhadap Islamisasi sains itu sendiri. Disini juga kita ketahui bahwa ide islamisasi sain itu muncul dari tiga tokoh utama yakni: Syed Houssein Nasr, Ismail Raji al-Faruqi dan Syed Muhammad Naquib al-Attas. 
Ide ini juga adalah bagian dari sebuah respon kaum muslimin terhadap ilmuilmu Barat yang diajarkan di negara-negara kaum muslimin di seluruh dunia. Barat yang dimaksud disini bukan lah Barat dalam artian geografis atau letak, tetapi Barat yang dimaksud ialah Barat dalam artian cara pandang Barat. Dimana akibat dari traumatis terhadap agama yang menjadikan kehidupan mereka tidak berkembang, membuat mereka membuang agama dengan segala atributnya, termasuk Tuhan. Cara pandang ini berpengaruh terhadap bagaimana mereka memandang kehidupan. Juga dengan bagimana mereka menghasilkan ilmu, ilmu pada akhirnya tidak dikaitkan dengan nilai-nilai ketuhanan.

Islamisasi bukanlah mengait-ngaitkan penemuan sains dengan ayat-ayat atau labelisasi, bukan juga sekedar menambahkan moraitas dalam penggunaannya, atau sekedar menggabungkan ilmu-ilmu umum dengan agama. Penegertian Islamisasi yang paling tepat menurut peneliti ialah: pembebasan manusia dari tradisi-tradisi yang berunsurkan kuasa sakti (magic), mitologi, animism, kebangsaankebudayaan yang bertentangan dengan Islam, dan sesudah itu pembebasan dari kungkungan sekuler terhadap akal dan bahasanya. Ia terbebaskan baik dari pandangan alam (worldview) yangberunsurkan kuasa sakti maupun pandangan alam yang sekuler.

Proses tersebut mengharuskan seseorang mengetahui secara mendalam mengenai pandangan hidup Islam dan Barat, maka proses Islamisasi baru dapat dilakukan. Sebabnya Islamisasi ilmu pengetahuan saat ini melibatkan dua proses yang saling terkait: Mengisolasi unsur-unsur dan konsep-konsep kunci yang membentuk budaya dan peradaban barat, dari setiap bidang ilmu pengetahuan modern saat ini. Khususnya dalam ilmu pengetahuan humaniora. Bagaimanapun, ilmu-ilmu alam, fisika dan aplikasi harus diislamkan juga khususnya dalam penafsiran-penafsiran akan fakta-fakta dalam formulasi teori-teori dan memasukkan unsur-unsur Islam beserta konsep-konsep kunci dalam setiap bidang dari ilmu pengetahuan saat ini yang relevan.

Jika kedua proses tersebut selesai dilakukan, maka Islamisasi akan membebaskan manusia dari magik, mitologi, animisme, tradisi budaya nasional yang bertentangan dengan Islam, dan kemudian dari control sekular kepada akal dan bahasanya. Islamisasi akan membebaskan akal manusia dari keraguan (shakk), dugaan (zann) dan argumentasi kosong (mira') menuju keyakinan dan kebenarn mengenai realitas spiritual, dan materi. Islamisasi akan mengeluarkan penafsiranpenafsiran ilmu pengetahuan kontemporer dari idiologi, makna dan ungkapan sekular.

\section{Referensi}

Al-Attas, S. M. N. (2010). Islam dan Sekularisme, bandung: Pimpin

Al-Attas, S. M. N. (2001). Risalah Untuk Kaum muslimin, Kuala lumpur: ISTAC.

al-Faruqi , I. R. (1984). Islamisasi Pengetahuan, Bandung: Pustaka

Armas, A. (2015). Makalah Kuliah Filsafat Islam, Epistimologi Islam dalam Pandangan Syed Muhammad Naquib al-Attas, Disc Masjid UI

Armas, A. \& Kania, D. D. (2013) Sekularisasi Ilmu dalam Filsafat Ilmu Prespektif Barat dan Islam, Depok: Gema Insani

Bertens, K. (2014). Ringkasan Sejarah Filsafat, Yogyakarta: PT Kanisius

Daud, W. M. N. W. (2013). Islamisasi Ilmu-ilmu Kontemporer dan peran Universitas Islam dalam konteks Dewesternisasi dan Dekolonisasi, Bogor: UIKA Bogor dan CASIS-UTM

Daud, W. M. N. W. (2003). Filsafat Pendidikan Islam Syed M. Naquib Al-Attas, Bandung: Mizan 
Handiarto, B. (2010). Islamisasi Sains sebuah upaya mengislamkan Sains Barat Modern, Jakarta: Pustaka al-kautsar

Handiarto, B. (2016). Sains islam: Makna Filosofis dan Model Islamisasi dalam Islamic Science paradigma, fakta dan agenda, Jakarta: Insists

Ishaq, U. M. (2014). Menjadi Saintis Muslim, depok: Indie Publishing

Kartanegara, M. (2003). Menyibak Tirai Kejahilan, Pengantar Epistimologi Islam, Bandung: Mizan

Saefuddin, A. M. (2010), Islamisasi Sains dan Kampus, Jakarta: Ppa consultan

Saefuddin, A. M., et al (1987). Desekularisasi Pemikiran Landasan Islamisasi, Bandung: Mizan

Sardar, Z. (2000). Jihad Intelektual, Surabaya: Risalah Gusti

Syarif, N. (2015). Menangkal Virus Islam Liberal, bandung: persis Press

Tafsir, A. (2013), Fisafat Ilmu Mengurai Ontology, Epistimologi dan Aksiologi Pengetahuan, Bandung: Rosdakarya

Tafsir, A. (2016). Filsafat Umum akal dan hati sejak Thales sampai capra, Bandung: Remaja Rosdakarya

Thalib, M. (1999). Melacak kekafiran Berfikir, yogyajarta: Wihdah Press

Zarkasy, H. F. (2014). Membangun Peradaban Dengan Ilmu, Depok: Kalam Indonesia 